\title{
Revealing gender discourses in the Qur'ān: An integrative, dynamic and complex approach
}

\begin{tabular}{|c|c|}
\hline $\begin{array}{l}\text { Authors: } \\
\text { Ghasem Darzi } \\
\text { Abbas Ahmad } \\
\text { Musa Nushi }\end{array}$ & land ${ }^{2}$ (1) \\
\hline $\begin{array}{l}\text { Affiliations: } \\
{ }^{1} \text { Department } \\
\text { Systems, Facu } \\
\text { Mining Resea } \\
\text { Shahid Behes } \\
\text { Tehran, Iran, I } \\
\text { Republic of }\end{array}$ & $\begin{array}{l}\text { furan's } \\
\text { Ity of Qur'an } \\
\text { ch Institute, } \\
\text { ti University, } \\
\text { slamic }\end{array}$ \\
\hline $\begin{array}{l}{ }^{2} \text { Department } \\
\text { Civilization of } \\
\text { Faculty of Rel } \\
\text { Shahid Behes } \\
\text { Tehran, Iran, I } \\
\text { Republic of }\end{array}$ & $\begin{array}{l}\text { f History and } \\
\text { the Muslims, } \\
\text { gious Studies, } \\
\text { ti University, } \\
\text { slamic }\end{array}$ \\
\hline $\begin{array}{l}{ }^{3} \text { Department } \\
\text { Language and } \\
\text { Faculty of Lett } \\
\text { Humanities, S } \\
\text { University, Tel } \\
\text { Islamic Repub }\end{array}$ & $\begin{array}{l}\text { f English } \\
\text { Literature, } \\
\text { ers and } \\
\text { nahid Beheshti } \\
\text { ran, Iran, } \\
\text { ic of }\end{array}$ \\
\hline $\begin{array}{l}\text { Correspondin } \\
\text { Ghasem Darzi } \\
\text { gh_darzi@sbu }\end{array}$ & $\begin{array}{l}\text { author: } \\
\text { ac.ir }\end{array}$ \\
\hline $\begin{array}{l}\text { Dates: } \\
\text { Received: } 03 \mathrm{~J} \\
\text { Accepted: } 06 \\
\text { Published: } 27\end{array}$ & $\begin{array}{l}\text { ly } 2020 \\
\text { Jov. } 2020 \\
\text { lan. } 2021\end{array}$ \\
\hline $\begin{array}{l}\text { How to cite th } \\
\text { Darzi, G., Ahm } \\
\text { Nushi, M., } 202 \\
\text { gender discou } \\
\text { Qur'ān: An int } \\
\text { dynamic and } \\
\text { approach', HT } \\
\text { Studies/Theol } \\
\text { 77(4), a6228. } \\
\text { org/10.4102/l }\end{array}$ & $\begin{array}{l}\text { is article: } \\
\text { advand, A. \& } \\
1 \text {, 'Revealing } \\
\text { ses in the } \\
\text { egrative, } \\
\text { omplex } \\
\text { Teologiese } \\
\text { gical Studies } \\
\text { tttps://doi. } \\
\text { ts.v77i4.6228 }\end{array}$ \\
\hline $\begin{array}{l}\text { Copyright: } \\
\text { (C) 2021. The A } \\
\text { Licensee: AOS } \\
\text { is licensed unc } \\
\text { Creative Comr } \\
\text { Attribution Lic }\end{array}$ & $\begin{array}{l}\text { uthors. } \\
\text { S. This work } \\
\text { ler the } \\
\text { lons } \\
\text { ense. }\end{array}$ \\
\hline Read online: & \\
\hline 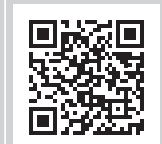 & $\begin{array}{l}\text { Scan this QR } \\
\text { code with your } \\
\text { smart phone or } \\
\text { mobile device } \\
\text { to read online. }\end{array}$ \\
\hline
\end{tabular}

This study examines the Qur'ān's view towards gender and argues that all three masculine, feminine and egalitarian (gender-inclusive) discourses exist in its text, and that these discourses do not follow a simple and linear model but rather a nonlinear and complex one. It also provides evidence, showing that gender equality in the Qur'ān is achieved in two ways: firstly, through linguistic devices that are devoid of gender distinctions, and secondly, through concurrent use of masculine and feminine gender markers in one context. The masculine discourse is, however, more prominent in the verses of this book and manifests itself to varying degrees in three ways: (1) in some verses, only masculine indicators are used but it can be inferred based on the (Taghlib) principle that both men and women are the intended addressees; (2) in some verses, rules regarding women are stipulated, whilst men are, in fact, the main addressees and (3) in verses that state rules on reciprocal issues such as divorce and marriage but these rules are addressed to only men. The feminine discourse is also present in the Qur'ān and can be seen in verses that address women.

Contribution: Revealing gender discourses in the Qur'ān requires not only a historical but also an integrative and holistic understanding of its text. This study attempts to identify the relation of the Qur'ān to the three gender discourses based on the linguistic elements of the text and their classification.

Keywords: the Qur'ān; discourse; text analysis; gender equality; feminine; masculine.

\section{Introduction}

Text analysis is one of the most effective methods for studying gender discourse(s) (West, Lazar \& Kramarae 1997:119) in a text. The three gendered discourses in this area that researchers are generally interested in are masculine, feminine and egalitarian (gender-inclusive). Societies, indeed, play an important role in constructing and directing the use of these gender discourses within a text (West et al. 1997:119). However, gender relations are complex, and their emergence is not necessarily discernible in a linear fashion, particularly in a text such as the Qur'ān, which was revealed to Muhammad over a period of 23 years and has witnessed tumultuous times. For this reason, a discourse analysis of its text would help better clarify its gender relations, as it is a research method that allows examination and evaluation of different applications of linguistic elements in written or spoken texts and their relation to the social context (Paltridge 2012:1; Tannen 1994:74). Therefore, one should observe and evaluate various aspects of the Qur'ān's language regarding the gender.

A large volume of works on the issue of gender representation in the Qur'ān thus far have been published. One of the most relevant of these works is a book by Naima Dib (2009) D'un islam textuel vers un islam contextuel: la traduction du Coran et la construction de L'image de la femme. The author depicts the social representations in the form of ideologies, which occupy the minds of the Qur'ān translators. She believes that views on women in the Qur'ān are not truly associated with the Qur'ān but are generally derived from the visions dominating the minds of the Qur'ān translators and commentators. She extracts two basic perspectives based on this hypothesis: firstly, the fundamentalist movement of Mohammad Abduh who was a critic of polygamy, and secondly, a perspective that is founded on the historicity of the Qur'anic text. These perspectives generally offer modern readings according to human rights values. What is important about the approach taken by this feminist Qur'ānic researcher is her belief that the translators of the Qur'ān are generally and subconsciously male dominated (Dib 2009). It is obvious that Dib has also sought to extract the gendered discourse associated with the Qur'ān, but her attempt was to discover the type of discourse that governs the minds of the Qur'anic translators, not the discourse that can be derived from all Qur'ānic propositions. 
Similar to Dib, Barlas (2001) focused on the influence of the male-dominant discourse on the commentators' minds, and their masculine interpretations and readings of the Qur'ān. According to her research, women, just as men, have the right to read the Qur'ān with their feminist values. She ultimately seeks to establish a liberal and non-gendered reading of the Qur'ān; however, like Dib, she does it before attempting to identify the discourse present in the Qur'ān. In her other work, Barlas stated that the anti-women verses in the Qur'an are relatively limited but the dominant discourse of the Qur'ān is masculine (2006:255-273). She seeks to explain the relationship between the text of the Qur'ān and patriarchy (Rahmatulla 2017:161). To do this, she provides examples for the antipatriarchal foundation of the Muslim holy text (Qur'ān), claiming that these examples are incompatible with both traditional and modern understanding of the patriarchy (Rahmatulla 2017:161). The monotheism of God is the most important theological paradigm on which her work is based.

Having the Qur'ānic discourse in mind, Wadud-Muhsin (1995-1996) also sought a new and feminine reading of the Qur'ān. The hermeneutic approach of Amina Wadud is completely linear, meaning that her liberal interpretation of the Qur'an is made based on specific verses, which have been interpreted in a way to portray the female gender as the oppressed one (Rahmatulla 2017:96). Furthermore, 'gender' is reduced to 'female gender'; the 'gender justice' she seeks is somewhat imperfect and unfair (Hidayatullah 2014:29). Wadud has only paid attention to the propositions and phrases in the Qur'ān from which the reading of gender injustice against women may be derived or it may prove gender justice towards women. Therefore, she has considered various themes from the story of Creation to the Day of Judgement, and she used text analysis and historical critique to do that. Meanwhile, some researchers (e.g. Milot 2009) sought to prove that the Qur'ān has an impartial approach towards male and female genders. It is clear that these researchers have not paid enough attention to the complexity of gender discourses in the book. It is important then that before forming any kind of judgment, we first identify the social relationships and discourses that exist in the Qur'ān, and then proceed to study the influence of the discourses on the minds of the translators and commentators of the book, a research endeavour that very few studies have sought to undertake.

Arguing that the Qur'ān mainly has a masculine discourse, Sadr sought to explain the philosophy and the reasons for such a discourse (Śadr 2001:112-131). From the author's point of view, the strong social participation of men during Muhammad's time is the main reason why Qur'ānic verses follow the male discourse (Śadr 2001:112-131). Smith and Haddad (1982:135-144) conducted one of the most important studies in this domain, focussing on the Qur'ān and Sunnah discourses regarding afterlife rewards for women and men. The researchers argued that there is a fundamental distinction between the Qur'ān and Sunnah approaches towards women and their afterlife rewards.
They maintained that despite the egalitarian views of the Qur'ann, male-oriented views dominate the Sunnah. In their viewpoint, in the Sunnah, women actions are largely dependent on the quality of their relationship with their husbands, and the degree of allegiance to their husbands defines their afterlife bliss. However, the case is different for men, where the quality of their relationship with God is the criterion for their everlasting prosperity. Such an approach is not observed in the Qur'ān, considering its heavy presence in the Sunnah. It is also noteworthy that Smith and Haddad's research centres on the content rather than on the linguistic indicators of gender, a shortcoming that our research tries to avoid by focusing on the linguistic indicators of gender. We hasten to add that although there are already many works trying to demonstrate the Qur'annic discourse on gender or the status of women in the Qur'ān (for some examples, see Awde 2000; Fārūqi 1984:36-49; Lamchichi 1995:97-111); the main emphasis of those studies has generally been on the prevalent masculine readings of the Qur'ān and not what the text of the Qur'ān indicates.

Amongst the works that can be considered as background to this article, there are two important books that analyse and evaluate feminist studies pertaining to the Qur'ān and the methodologies that those studies adopt. These works are important because they can show the methodological differences between this article and the previous prominent works. Aysha Hidayatullah (2014) presented the first comprehensive analysis of contemporary feminist interpretations of the Qur'ān. Combining the prominent late 20th-century feminist readings of the Qur'ān in the United States of America, she provides a fundamental introduction to this nascent field of Qur'ānic studies. Focusing on the feminist dilemmas in the Qur'ān, she argues that many feminist commentators have relied on claims about feminist justice that are not fully supported by the Qur'ānic text. She, therefore, proposes a fundamental overhaul of their interpretive foundations.

Rahmatulla (2017) dealt with the important issue of 'liberation theology and gender justice in Islam', and tried to review and evaluate the readings of contemporary Qur'ānic scholars. In two parts of the book, he specifically deals with two prominent feminist Qur'ān scholars: Amina Wadud and Asma Barlas. Rahmatulla has called Wadud and Barlas' interpretations of the Qur' ān as '[w]omen's gender egalitarian readings of the Qur'ān'. He believes that these two researchers, rather than trying to draw a paradigm or describe the gender discourses of the Qur'ān, seek to present a different and feminine reading of the book, which is different from the common and masculine reading of the commentators. Rahmatulla (2017), therefore, provides cogent arguments, which show the difference between the present article and the works that have been published before, especially the works of Wadud and Barlas.

It should be noted that all the works that have been written so far about the Qur'ān and gender introduce 'historical 
return' to the text as a key element for their feminist reading. However, in this article, we do not seek historical return or 'historical understanding and critique' of the text. The purpose of this article was to identify the relation of the Qur'an with the three gender discourses based on the linguistic elements of the text and their classification. Moreover, in the aforementioned works, gender has been reduced to 'woman' (Hidayatullah 2014:128-129), whilst in the present article, we have a comprehensive look at all three masculine, feminine and egalitarian discourses and their different manifestations.

For this purpose, the authors of this article have tried to address the cultural dimensions of gender-related indicators in the Qur'ān. Such a perspective will better illustrate the network of cultural relations and gender-based power networks. In order to carry out the analysis, the Qur'annic verses that were related to gender in any form were identified and categorised based on whether they embodied a masculine, feminine or egalitarian approach. In the following sections, we draw a network of meaningful relationships about gender in the Qur'ān with a brief reference to these three approaches. Before doing so, however, we need to know how gender is represented in the Arabic language.

\section{Gender indicators in the Arabic language}

Languages differ greatly in their use of gender attributes. Some languages, such as Persian, demonstrate the least gender differentiation; masculinity and femininity are not defined in names and verbs, nor are the pronouns in this language marked for gender. For instance, the subject pronoun '〈u:' (s/he) at the beginning of a sentence is used for both males and females alike. ${ }^{1}$ In contrast, other languages, such as German and French, heavily use gender indicators. In German, all names are categorised into three main classes: masculine, feminine and neutral, and an appropriate article is required for each of these genders. ${ }^{2}$ Even the possessive pronouns change according to the gender of the noun in the sentence. The difference between the two phrases 'er ist mein Bruder' versus 'sie ist meine Schwester' 3 is observed; apart from the verb 'ist', the rest of the sentences is different according to their masculine or feminine gender. In English, the differences are more subtle, and the possessive pronouns are often gender independent. ${ }^{4}$ In contrast to some scholars who believe that Arabic is a highly gendered language (Badran 2002:vol. 2:288-292), the authors believed that the language holds the middle ground regarding genderness. It is neither like Persian in which gender indicators do not have a significant role in the structure of the language, nor like German or French, in which gender is an inseparable and

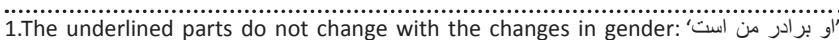

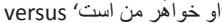

2.The three articles, die - das - der, have been considered for this purpose.

3.The underlined parts do not change with the changes in gender: 'er ist mein Bruder' versus. 'sie ist meine Schwester'.

4.The underlined parts do not change with the changes in gender: ' $[h]$ e is my brother' versus. 'she is my sister' ever-present controlling part of the sentence structure. In Arabic language, gender plays an important role and is one of the main factors in conjugation of verbs and nouns; moreover, the language contains rules, which lighten the presence of gender indicators and benefits gender equality. Three factors, including gender, simultaneously play a role in verb conjugation: 'absence (third person) and addressing (second person)', 'masculinity and femininity' and 'singularity, duality and plurality'. The most important factors in declension of nouns include 'gender', 'number', 6 'minimisation' (adding an affix to a word to convey the meaning of small or unimportant) and 'association' (Tasghir) (relational nouns). Perhaps, amongst these factors, gender plays a more prominent role as we may be faced with names that do not have any difference in their singularity, plurality, minimisation or association, yet it may still be necessary to affirm their gender. In other words, in Arabic language, 'neutral' has not been defined for nouns.

With regard to noun declensions and verb conjugation rules of the Arabic language, there are instances where gender does not have an active role. The 11th and 12th forms of the verbs ${ }^{7}$ are defined without any gender indicators. The verb forms «فعلن (Fa'altu) and «فعلن $\left(F a^{\prime} a l n \bar{a}\right)$ have no discernible gender indicators. In other words, the pronouns «تُّ (Tu) and «ن $(N \bar{a})$ do not have any gender specifications.

We face a different situation with nouns; regardless of whether they appear as a 'form' or as a 'word', we encounter instances where gender does not play any role. Within forms, irregular plural nouns can be mentioned as an example. Irregular plural nouns contrast with regular plural nouns, which have both masculine and feminine forms. ${ }^{8}$ Irregular nouns, however, are defined without any gender indicators and use a range of formats for compliance. The speaker's use of an irregular plural form rather than a regular one can serve the gender impartiality in their speech. As an example, instead of using the regular plural form 'استادون' (ustādün) and 'استادين' (ustādīn), we can use its irregular form 'استيد' (asātìd). ' It is clear that in Arabic, there exist no other differences between these two plural classes, except their gender. However, we will face a wider variety of words in the realm of singular nouns. Words such as '

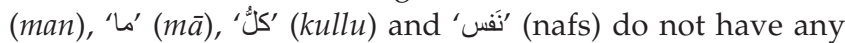
gender specifications and are used for masculine and feminine alike. Increased use of these words in Arabic can reduce the level of gender orientation in the language and strengthen the egalitarian approach in the text. Considering the above points, we try to provide an analysis of the Qur'ān's gender discourses.

5.Masculine and feminine.

6.Singular, dual and plural.

7.Singular and plural first person.

8.Masculine regular plural noun is formed by adding the suffix 'نَ' (ūnah) and 'نى (inah) to the noun and the feminine regular plural noun is formed by adding the suffix ' $\Xi$ ' (ateh) to the word's end.

9. The word 'استيد' (ásātīd) does not contain any gender indications. There are other meters in irregular plural form, which do not contain any gender signs, such as 'فعول'

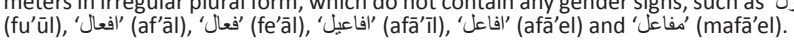


As mentioned in the previous section, Arabic language contains gender indicators, and gender plays a crucial role in conjugation of its verbs and declension of the nouns. Nevertheless, strategies exist to maintain gender equality when using the language. In this regard and considering that language users are also able to reduce excessive dominance of male or female gender discourse and adopt a more genderbalanced approach in their language production, we have identified gender propositions in the Qur'ān and have categorised them into three discourses: masculine, feminine and egalitarian. We introduce more detailed subcategories, as well as various types of each of these discourses later on in this article. This classification will show the extent to which the Qur'ān pays attention to each of these three discourses and the quality in which each is addressed. Furthermore, we try to identify the approaches of the Qur'ann in order to realise gender equality in the application of language. Content analysis was used as a research method to analyse the data in this study because it is a 'method that can be applied to written or visual materials for the purpose of identifying specified characteristics of the material [which] can be textbooks, newspapers, web pages, speeches, television programs, advertisements, musical compositions' (ed. Ary 2014:488).

Content analysis, which can be performed qualitatively (Schreier 2014) as well as quantitatively (Krippendorff 1989), is a widely used method (Hsieh \& Shannon 2005) to examine issues from the presence of certain words or concepts within texts or sets of texts to deep individual or collective structures, such as values, intentions, attitudes and cognition. There are usually two general categories of content analysis: conceptual analysis and relational analysis (Mills, Durepos \& Wiebe 2010). Conceptual analysis can be defined as considering the existence and frequency of concepts in a text. For instance, if a researcher wants to examine feminism in the poems of a favourite poet, he or she should find words related to feminism and their frequency. Nevertheless, relational analysis, which was applied in the current study, goes deeper by identifying the relationships amongst concepts in a text, for instance, by examining what comes before or after. Cohen, Manion and Morrison (2007) described content analysis as the process of four Cs, that is, coding, categorising, comparing and concluding. Coding is used to organise and reduce the data, and look for specific patterns within the data in order to connect them to broader concepts. Categorising is the process in which researchers try to group patterns observed in the data into meaningful categories. Comparing means establishing connections between categories. Finally, concluding stands for drawing theoretical considerations on the basis of the text and the results of the analysis (see Cohen et al. 2007).

A widely recognised benefit of content analysis for the researchers is the permission-free characteristic of the method, meaning that the researcher does not need to obtain permission from any participants or corporations (ed. Ary 2014). Using the method, the researchers went through the verses in the Qur'ān one by one and classified them based on their linguistic features into three categories: masculine, feminine and egalitarian. Each category was further divided into subcategories, given the genderedness of the verses. The method allowed the researchers to demonstrate not only the three gender discourses in the Qur'ān but also the degree of genderedness of those discourses.

\section{Egalitarian (gender-inclusive) approach in the Qur'ān}

From a gender perspective, an egalitarian approach in the language is achieved either by application of non-gendered devices or by equal use of both masculine and feminine gender indicators. Therefore, the examination of linguistic indicators associated with the egalitarian approach presents us with two different patterns: (1) application of gender-free

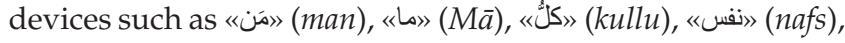
and (2) concurrent use of male and female gender indicators within one context, an approach to gender that has been used extensively in the Qur'ān's text. The two patterns are elaborated in the following sections.

\section{Application of gender-free devices}

One of the solutions to promote justice and gender equality in Arabic language is using words without gender indicators, which can be employed for both masculine and feminine genders. The devices include «نَ" (man), «ما» $(M \bar{a})$, «لَ"

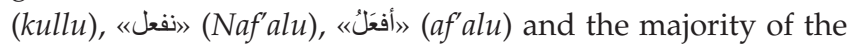
irregular plural forms. Applying such words when their gendered equivalents are also applicable can indicate the conscious effort of the speaker to achieve gender equality. We encounter two types of language use: Type 1 when gender-free language devices are applied from the beginning of speech, and Type 2 when the speech is initially dominated by a gendered approach, generally masculine, but is replaced by the gender-free language devices when the main statement is made. The second type is known as gender grammatical shift (Iltifāt al-jinsī). Gender grammatical shift is a technique that has been extensively applied in the Qur'ān and in presentation of gender equality can be more prominent than the first type, as it implies a greater emphasis on gender equality in the language. Haleem (1992) wrote in detail about this literary feature and its use in the Qur'ān (see more in Haleem 1992:407-432). In the following, we present examples of both types.

\section{Type 1: Application of gender-free devices and gender equality in the language of the Qur'ān}

Relative pronouns, such as «نَ" [who] and «L» [what/ whatever], are amongst the most widely used gender-free devices in the Qur'ân. The following sentence is a small example of these instances. In verse 3:126, Allah uses the relative pronoun ' $\mathbf{}$ ' [what/whatever] to declare his rule over the heavens and earth. 'L [whatever], with its gender-neutral character, emphasises more on such a declaration rather than words and devices that possess specific gender characteristics. Furthermore, in this verse, the words 《شىی [things] and «كلّ" 
[of all] are devoid of gender indicators and support the mentioned declaration of that rule.

Another illustrative example is Qur'ān 57:4 where the use of the relative pronoun 'us' has created a type of alliteration in the text, and the relatively meaningful distinction of the first four ' 1 's in the beginning, and the 'م' that is finally added to 'أينَ' brings a special form of Qur'ānic punning to mind. ${ }^{10}$ However, what is specifically desirable here is the generalisation that has emerged using the gender-neutral ' 1 ' statements. The repetition of this non-gendered term in the text represents an egalitarian view, addressing all the creatures of God and suggesting that all creatures are equal in the eyes of God.

An alliteration similar to what we saw with the use of the word «L»" [what/whatever] is also seen when using the word «نَ» [interrogative who] in Qur'ān 10:31. In this verse, the similarity of sounds between «نَ"/[who] and «ن”/[from] is well applied, and with its repeated use in one sentence, much more emphasis on and exaggeration for the word "نَ" has been created. The generality of this term is amplified by the absence of gender indicators. Words such as "كلُّ" [all],

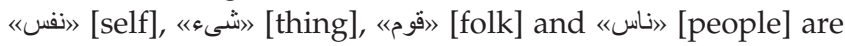
also amongst gender-neutral language devices, which are applied in the Qur'ān. In Qur'ān 3:26, Allah, in order to illustrate the dominance of death, uses the two words «كلّ and «نفس» together. Moreover, the use of the word «نَ" in this verse also emphasises gender neutrality and encompasses both male and female gender. In Qur'ān 4:126, as discussed earlier, in addition to the word «ما", the two words «لُّ" and 《شی were used together, which also depict the use of devices that are gender neutral.

Investigating the Qur'annic samples presents the researchers with a large volume of these applications, which increases the egalitarian polarity of the Qur'ānic discourse, but the gender grammatical shift more significantly denotes the conscious use of equality in the gendered application of the speech and has led to the distinctive prominence of the egalitarian approach within the text of the Qur'ān.

\section{Type 2: Gender grammatical shift and gender equality in the language of the Qur'ān}

Gender grammatical shift is a change from a certain gender indicator to another within a single linguistic context. What we mean by the gender grammatical shift in the Qur'an is the transformation of male gender devices into gender-free devices. In traditional topics, such a shift also implies the generalisation and deliverance of judgements (see Suyūtī 2000:2/123-124). However, what matters most to us is the prominence of the egalitarian discourse. Qur'ān 2:108 and 2:212 begin with the plural masculine forms «الذين كفروا) [those who disbelieve] تريدون - [you intend]» but near to the end and when God's command is declared to the people, "s [who]» is applied. As mentioned before, «م [who]» is amongst the non-gender-based devices. Therefore, here, a gender grammatical shift and transition from plural masculine to gender neutral has occurred. This gender grammatical shift not only allows the verdict of the verse to more explicitly encompass both men and women but also enables gender equity to manifest itself more noticeably in the application of the language. We should not fail to mention that whilst examples like the above are abundant in the Qur'ān, this form of gender grammatical shift has scarcely occurred in other contemporary texts of the Qur'ān or later works. This gender grammatical shift is clearly observable in Qur'ān 2:80-81.

In Qur'ān 2:80, God uses the verb «قالوا》 [they say] in a masculine plural form up to the end of the verse. In verse $2: 81$, which a generalised rule applying to both men and women, the pronoun «نَ» is used. This shift from a masculine plural form to a singular genderless form is an important gender shift. A similar example can be seen in Qur'ān 3:196,

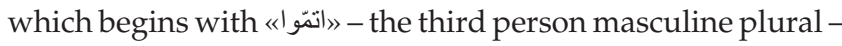
but when the general law is stated, the word «نَ» is applied. Other similar instances can be seen in Qur'ān 16:105-106. Shifting from gendered verb forms to neutral verb forms is amongst the prominent features of the Qur'an language. Verse 3:191 is a good example of such a transition; in this verse, we observe the transition from the third person plural يذكرون [who give thought]» and بنفكّرون [who remember]) to the first person plural «بَّنَّ [our God]». This is a transition not only in number (third person plural to first person) but also in gender as the first person plural (pronoun «ن [we]) is devoid of any gender indicators. Therefore, the gendered view is dominant in the beginning of the verse but the view is egalitarian in the continuation and towards the end.

It is apparent that grammatical gender shift plays an important role in establishing gender equality in the language of the Qur'ān. In other words, God does not necessarily follow the common rules of the Arabic language, where it is customary for male singular and plural pronouns to represent both male and female genders. Therefore, masculine pronouns can be used generically to refer to both sexes, but the gender grammatical shift makes a fundamental difference in this regard, that is, it adds to the generalisation and weakens male gender dominance through introducing gender-neutral devices in the male-dominated context. Another important type of language use found in egalitarian discourse, which is more prominent, is the concurrent use of male and female gender indicators within the same context, a topic that will be dealt with below.

\section{Concurrent use of male and female gender indicators within the same context}

Another important linguistic feature employed in the Qur'ān is the concurrent use of male and female gender indicators in a linguistic expression. To do lingual justice to both genders, application of this feature is much more important than the previous one (i.e. gender grammatical shift), as it shows the conscious application of an egalitarian approach through the use of female indicators alongside the male 
ones, although it is possible to generalise the rule using only masculine indicators. Numerous and wide-ranging examples of this pattern can be found in the Qur'ān, which come in the following two forms:

- Application of two sentences with the same meaning but with different gender forms: here, the language user covers a single subject or content in both of its masculine and feminine forms, whilst in most other applications, masculine style dominates the generalisation and envelopes female gender. However, there are significant applications in the Qur'ān in which male and female genders are presented alongside each other. Four verses in the Qur'ān (Sūra al-Nisāa) are worth mentioning in this regard. In verses $4: 7$ and $32,{ }^{11}$ Allah emphasises in a similar way that men and women can claim their inheritance after the death of their relatives. Insistence on a similar and closely related concept in two distinct ways, where the main difference is in gender, is highly notable.

Qur'ān 4:15-16 deal with the subject of depravity and illegal sex. Qur'ān 4:15 begins with the relative pronoun and plural feminine verb, and throughout the verse all the verbs and pronouns are entirely in the feminine form. Nevertheless, Qur'ān 4:16 suddenly changes the gender approach to masculine, that is, the relative pronoun and the plural verb begin in masculine form and hold this gender until the end of the verse. These two verses address a social pathology and the policy to deal with it. In such a case, it was important that both masculine and feminine texture should be considered together. Verse 4:35 is another example, which talks about family conflicts and the dispute between a husband and wife. Here too, when it comes to discussing the ruling between the husband and wife, gender equality is emphasised; so once in a masculine fashion (an arbitrator from his people) and once again in a feminine way (an arbitrator from her people), the judgement is explained. It is observable in this Surah that for the presentation of all issues, whether positive or negative, similar gender references are applied, and there is a particular emphasis on the attainment of gender equity in language use in these applications:

- The second way in which gender indicators are used concurrently to represent gender equality in the Qur'ān is the incorporation of male and female nouns in a sentence or language context. It includes the concurrence of male and female gender symbols in a single proposition and phrase. In the previous pattern, different gender indicators were presented in two textures and propositions. Qur'ān 4:75 speaks about the rights of the weak and the most vulnerable, whether men, women or children:

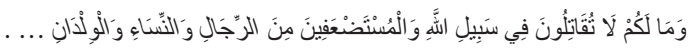

Translation: (And what is [the matter] with you that you fight not in the cause of Allah and [for] the oppressed amongst men, women and children) ....

11.We have tried to include the verses we cite in this article but that was not always possible because of space limitation. We, therefore, had to suffice to citing the verse numbers only.
In this statement, it is stressed that women should be included along with men. In the following verses, the words related to male and female gender have occurred together to represent the unethical subjects and social pathologies, such as stealing, hypocrisy and theft:

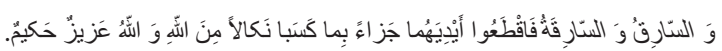

Translation: $[$ As for $]$ the thief, the male and the female, amputate their hands in recompense for what they committed as a deterrent [punishment] from Allah. And Allah is Exalted in Might and Wise. (5:38)

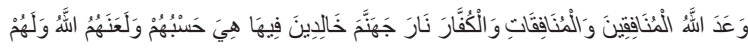

$$
\begin{aligned}
& \text { عَذَابِّ مُقِمِّ. }
\end{aligned}
$$

Translation: Allah has promised the hypocrite men and hypocrite women and the disbelievers the fire of Hell, wherein they will abide eternally. It is sufficient for them. And Allah has cursed them, and for them is an enduring punishment (9:68).

Similarly, in Qur'ān 24:2, God says:

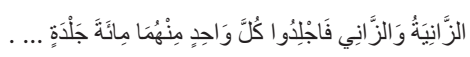

Translation: The [unmarried] woman or [unmarried] man found guilty of sexual intercourse - lash each one of them with a 100 lashes....

In these cases, in contrast to the dominant masculine approach in which the inclusion of the feminine gender is only based on the domination principle, there is an emphasis on the female gender. In the first two verses, firstly the masculine and then the feminine gender have been presented - the male thief (السارق) and the female thief (السارقة);

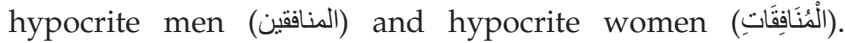
However, in the third verse, the unmarried male individual (الزَّاني) is followed by an unmarried female person (الزَّانيَِنَ).

Such an approach, however, does not only apply to verses with negative content. Verse 33:35 is one of the most prized Qur'ānic verses, which demonstrates the characteristics and attributes of exemplar Muslim men and women. This verse insists that the attributes of faith in men and women should be applied based on their own gender appropriate language. The extent to which the male and female gender indicators have come together, almost in a eulogistic style, provides this verse with a unique feature in achieving gender-based linguistic justice.

All of the above examples show that the egalitarian approach is a significant and prominent approach in the Qur'ān, which cannot be easily overlooked and replaced by a simplistic approach of the masculine domination. Nevertheless, it is important to note that the male language approach prevails in the Qur'ān. At this point, in order to form a better judgement, we also illustrate the cases of masculine approach in the Qur'ān.

\section{Masculine approach in the Qur' ān}

Another category of verses the linguistic examination of which shows a gendered approach includes those verses that have a male-dominant approach. These verses constitute a 
large volume of the Qur'ān. Assessment and analysis of the most important verses of this category present us with four different approaches: (1) verses that have a masculine approach and also include women, following the 'Taghli $b^{\prime}$ [domination] principle, (2) verses that explain the rules that are related to women but whose addressees are men and use a masculine texture to present them (i.e. the rules), (3) verses in the form of statements that have a dual nature but are only addressed to men and expressed in a masculine form and (4) verses that adopt a humiliating and at times offensive approach towards the female gender.

The first category of the verses that are noteworthy within the masculine approach in the Qur'ān includes those that express a general verdict for both genders through male pronouns and verbs. Such a practice is generally justified by the principle of 'تغليب' [domination], which is defined by the Qur'ānic scholars as the transfer of a rule from one entity to another. In other words, it is the preference of one of the dominated over another and the application of the term 'dominant'12 to both objects (al-Zarkashī 1984:vol. 3/369; Ibn al-Athīr 1933:2/4; Suyūtī 2000:vol. 3/253-259). It should be noted that 'domination' is a common thread in the Qur'ān. The extent of the use of such domination in the Qur'an is because of the conformity between the Qur'annic language and the essence of the Arabic language, as such a domination is very common in the Arabic language (Abūzayd 2000:30-31). According to Abūzayd, the principle of domination, through which male gender linguistic devices are used to refer to female gender as well as to refer to issues related to both men and women, is widely used in the Arabic language. This feature of the language cannot be considered a shortcoming of the Qur'ān.

In most of the Qur'ānic cases, a verdict, which is generalised to all human beings, is made through the use of male pronouns as the generic. Two of these numerous examples include the use of masculine gender indicator 《بنىى》 [sons] to refer to the children of Adam (a) in Qur'ān 7:27: General rules such as the one on charity in Qur'ān 2:271, which is explained via a masculine approach, are also worth mentioning:

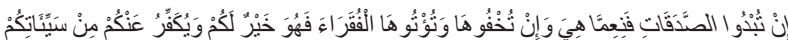

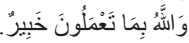

Translation: If you disclose your charitable expenditures, they are good; but if you conceal them and give them to the poor, it is better for you....

One of the most challenging of these dominant generalisations can be seen in the verses where God speaks of the believers' rewards and introduces descriptions of heavenly blessings. In such verses, the gender is generally masculine and the promised rewards are meaningful for men. These verses usually begin with the dominant Qur'annic approach, the masculine approach, but with the possibility of

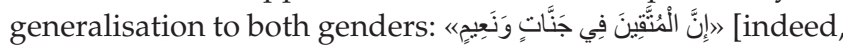
the righteous will be in gardens and pleasure] (Qur'ān 52:17).

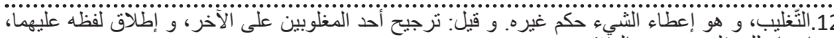
إجر اء للمختلفين مجرى المتنفقين
However, in the following, the conditions give rise to the suspicion that the blessings are specific to men: 》" (they will be reclining on thrones lined up, and we will marry them to fair women with large, [beautiful] eyes) (Qur'ān 52:20). Other similar verses in the Qur'ann provide stronger evidence for such an assignment of rewards. Examples of such include verses (Qur'ann 56:35-37) that describe the rewards of the believers to be maiden women. In order to introduce these maidens, female pronouns have been applied, which leaves no doubt that they are exclusively women. For example, we refer to Qur'ān 52:24 that speaks about teenage boys [Qīlmān] whose duty is to serve in Paradises. Despite the challenges mentioned above, these verses with their masculine approach constitute a large portion of the Qur'ān. The generalisation and domination can be observed in most of them.

The second category of the Qur'ānic verses that portrays the masculine approach includes those that state the rules related to women, whilst, in fact, those rules are addressed to men. Given that women have been addressed in the Qur'ān in numerous instances, it is meaningless to assume that God has not addressed the women in order to protect their dignity in these verses. There is no doubt that respect to women has been given the highest possible degree in the Qur'ān, but justification of the uses of the abovementioned category of verses cannot be only based on the respectfulness hypothesis. In Qur'ān 2:222, which specifies the rules about women's menstruation, Allah declares in a purely masculine style to say how men must withdraw from women and not have sexual intercourse with them. In this verse, without specifying what those women should do, the verdict addresses the men. The only other verse in which the rules about menstruation have been mentioned is Qur' ān 65:4, in which the main issues are the period [عَده] for specific women, menopause and pregnancy, at the time of their divorce. Interestingly, in these verses, there is also a conditional clause the grammatical gender of which is masculine, 'if you doubt' [إن ارتنتُم] and presents a male discourse.

The third group of male-oriented verses relates to the laws in the Qur'ān, which have a reciprocal nature but proceeds by addressing only the men. Interestingly, many Islamic jurists (see Jaśs̄às 1984:1/190; Mohaghigh Helli 1987:3/3; Zahili 1988:9/6877), given the masculine gender of the addressees, do not believe that these verses can be generalised to include the female gender. The issue of divorce and marriage is one of the most important subjects that fall under this category. Although these two important social issues are reciprocal in nature, with the authority of both men and women involved, in the Qur'ann they are presented with a focus on male audience. In verse 33:53, the ban on marriage with Prophet Mohammad's wives is mentioned. Here, marriage is presented in a unidirectional and masculine style too. In verse 60:10, although there is a passing remark about the

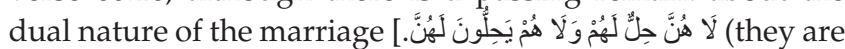
not lawful [wives] for them, nor are they lawful [husbands] for them), much like the preceding verses, the masculine discourse prevails. 
The only part where the Qur'ān regards the marriage from the feminine point of view is on the subject of a woman marrying her former husband. In Qur'ān 2:232, Allah states that women should not be prevented from marrying their former husbands following their divorce and after the allocated time has passed. This is the only instance when the verb marriage is presented through the feminine approach [يَنْكِنْنَ أَزْواجَهُنَّة, and shows women's control and choice in marriage. This verse also begins with a masculine orientation

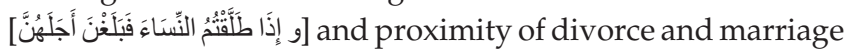
can be a good introduction to the issue of divorce and the Qur'ān's gender approach towards it. A similar approach towards divorce is also observable in Qur'ān 2:227, in which Allah mentions men as those possessing the intention and determination for divorce. In the same Surah, Qur'ān 2:229 confirms this approach after expressing the number of permitted divorces by using a masculine pattern. Moreover, in Qur'ān 2:230, the use of masculine pronouns and style leaves no doubt about the adoption of a masculine approach. The presence of the word «" طأقّها》 [he divorced her] confirms that the divorce takes place by the will of the man.

Despite what was mentioned about the reciprocal nature of divorce and marriage in this section, and the adoption of a one-sided, masculine approach by the Qur'ān in covering these issues, the various perspectives of the Qur'ān towards women make it really difficult to draw a firm conclusion on whether adopting a masculine approach in these verses means denying women the right to make their choice in divorce and marriage. The complexity of the Qur'ān's language regarding the issue of gender makes it tricky to draw gendered and biased conclusions solely from the masculine or feminine use of the language. Our argument is whether the use of the domination principle and generalisation through this principle impact the verdict and make the verdict biased. A look at the uses of language in the Qur'an shows that in many cases, the rulings based on domination are general and not biased. It is highly questionable, therefore, to assume that rulings regarding issues, such as divorce and marriage, which have been issued based on the principle of domination, are biased in favour of the masculine gender.

The fourth and the last category of the series of verses that has a masculine approach relates to verses that follow a humiliating and at times offensive approach towards the female gender. Many of these features that are discussed further are because of the masculine nature of the Arabic language, which the Qur'ān has also applied in its style of speech. As an example, in Arabic, certain forms that are frequently followed by feminine signs are used for

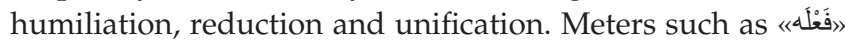

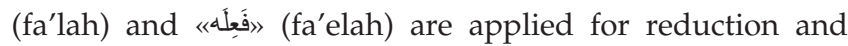
unification. Also, a mixture of indefinite and feminine is mostly used for humiliation. Such application is observable in Qur'ān 2:280 where we are confronted with words, such as 》نَظْرَة indicate paucity and shortage, and their feminine style plays an important role in this indication. Of course, as we mentioned, this is mostly rooted in the masculine nature of the Arabic language.

Adherence to the masculine discourse with a subordinate view towards the feminine gender has been taken more seriously in some verses of the Qur'ān. In Qur'ān 4:34, two successive phrases refer to the domination and dominance of men over women:

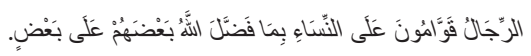

Translation: Men are in charge of women by [right of] what Allah has given one over the other.

In the second part of this statement, men's dominance over women is considered as a reason for the dominance of men towards women. The masculine severity in this phrase has led some to proceed with a feminine retrieval of the concept of «قو امها" 'Qawāma' and 'the supremacy of the husband'. At the end of verse 4:34, hitting women in the event of her nonadherence to marriage «نُشُخ 'Nush $\bar{u} z$ ' is mentioned. The image of women in this verse is such that she does not possess any rights for sexual intercourse, and to some extent, can be considered a 'bondwoman' or 'sex slave'. It seems that the metaphor for 'bondwoman' and 'captive' is visible for women in some other verses.

There are numerous indications for this issue in Qur'ān $2: 229$, the beginning of which it is said that after a divorce, the man has the right to return to his wife and resume his life with her or release her «تسريح باحسان (release [her] with good treatment). The phrase 《تسريح باحسان باحسان repeats again in Qur'ān 2:231 as if the woman is captive and the man is free to keep or release her. However, there is a

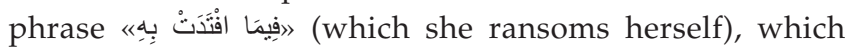
suggests more clearly the similarity of the woman to the 'captive'. The use of the term 'فنيه' (Fadiah), meaning the price that the woman pays to have her divorce license issued, is quite similar to the verse $47: 4$ in which a captive can pay a fee to buy his freedom: فَإِكَا مَنَّا بَعْدُ وَإِمَّا فِدَاءُ (and either [confer] favour afterwards or ransom [them]). Therefore, in Qur'ān 2 (Sūrah al-Baqarah), the resemblance of a woman to the captive indicates the condescending look on her. Similar to what we have seen with the use of the 'captive' metaphor for women, but with a little difference, there exists a discussion in Qur'ān 4 (Sūrah alNisāa), which is related to the inheritance of women despite their reluctance:

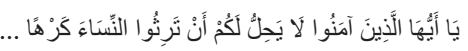

Translation: $\mathrm{O}$ you who have believed, it is not lawful for you to inherit women by compulsion.

In this verse, the woman is considered as a bondswoman or a commodity whose inheritance is possible by the heirs.

Another instance in the Qur'ān which can, on the surface, confirm and reproduce the humiliating look of the people of 
the age of the Prophet Mohammad towards women is where God reprimands the non-believers' idea that the angels are the daughters of God. These were the times when people preferred to have sons, and there existed a sort of hatred and disgust amongst them towards having a daughter. Based on this discriminatory belief, Qur'ān 53:21 states in a surprising statement: ' $i$ i]s the male for you and for Him the female?'. In this passage, the discriminatory and inferior view towards women has been verified. However, another similar verse, verse $4: 117$, is more discriminatory with more precise and more direct definitions. Firstly, the concurrent

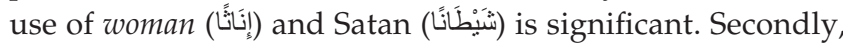
the phrase 'They call upon instead of Him none but female [deities]', rather looks down on the female gender. In verse 3:36, which describes Maryam (Mary)'s birth and her mother (Hannah)'s discomfort with having delivered a female child, one can also discern the same view. In the remainder of the verse, if we consider Maryam's mother to be the narrator of the phrase ' $[a]$ nd the male is not like the female', a rather unanimous belief on the part of the audience in superiority of the male over the female gender is evident.

A number of other verses that might seem to promote an insulting and inferior look towards women are those that allude to women's soft upbringing and lack of strength in taking up social responsibilities. In verse 2:282, for instance, it is argued that the reason why the testimony of two women would equal that of one man is that in case the first woman forgets a fact, the other woman reminds her of it:

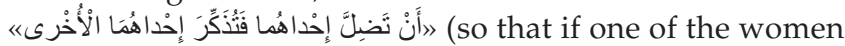
forgets, then the other can remind her). It is clear that 'forgetfulness' here is considered as a defect in women and has created a lower position for them than men. Verse 43:18 also mentions the flaws of women in arguments and discussions, through which an inferior view takes place:

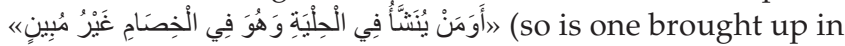
ornaments whilst being during conflict unevident [attributed to Allah]?)

The four different patterns of masculine approach in the Qur'annic language and the effect of the male-dominated language do not reflect the unquestioning domination of this discourse on the language of the Qur'ān. The egalitarian approach discussed at the beginning of this article and the feminine approach that will be analysed further on constitute a significant number of the Qur'ānic verses. This reveals that gender-specific discourses have a complicated representation in the Qur'ān, and that we are faced with a combined application of discourses within its text. In the following section, we concentrate on the Qur'annic verses in which the female approach is dominant. The third category, much like the first category, serves the egalitarian approach.

\section{Qur'ānic verses with dominant feminine approach}

The next gender-based linguistic pattern that can be observed in the Qur'an is the feminine approach. These verses are amongst the most distinct Qur'ānic approaches, and this distinction is because of the fact that many similar compositions are not fundamentally consistent with this approach. These verses can be grouped into two categories: In the first category, women are addressed, and in the second category, we see women being cited as role models. The feminine models in these verses are not just for other women, but men can also consider them as their own model.

\section{Direct addressing of the women in the Qur' ān}

As mentioned in the previous section, addressing women is not a common strategy in the Qur'ān. As was mentioned, gender grammatical shift is a popular literary device in the Qur'ān, which prevents the direct addressing of women. In fact, in the cases that follow the grammatical shift, women's verdict is mentioned through addressing the men. It is useful to regard this alongside the fact that such an approach happens even when it is possible to directly address the

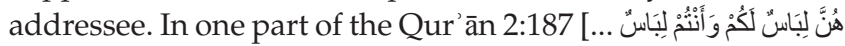
هَنَ (.... (..they are clothing for you and you are clothing for them (... .], we see that men are being directly addressed (انتُ)), whilst it is possible to address the women as well; they (i.e. women) are mentioned in the third person (هنَّ).

We also see the same approach when the rules regarding the quality of mothers' breastfeeding (رضاعه) are mentioned. Although it is possible to address the women directly, they are mostly mentioned in the third (absent) person. In addition to these instances, there are verses in the Qur'ān in which women are addressed directly. Allah addresses Maryam in one of the most prominent examples of this type:

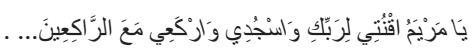

Translation: O Mary, be devoutly obedient to your Lord and prostrate and bow with those who bow [in prayer]. (3:43)

Reflecting on the previous sections shows that the direct addressing of women in the Qur' ān is considered a rare and important event. Application of female verbs 《قنتى-اسجُدى- اركَعى [be obedient - prostrate - bow] in a succession has given a special weight to the female gender in this verse. Evidently, addressing of women is not limited to Maryam. Elsewhere in the Qur'ān 33:30, God addresses the Prophet Mohammad's wives directly and warns them against the practice of sexual immorality. Also, in another important verse, God speaks of the revelation to the mother of Moses. In the following example, Allah narrates his discussion with her:

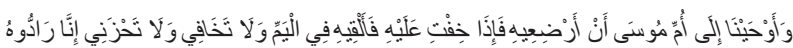

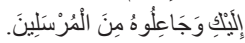

Translation: And We inspired to the mother of Moses, '[s]uckle him; but when you fear for him, cast him into the river and do not fear and do not grieve. Indeed, we will return him to you and will make him [one] of the messengers'. (28:7)

The revelation to a woman in the Qur'anic discourse is so important that it has become the subject of specific studies by Islamic feminists (e.g. see Ismail 1999). The recurring use of the second person female verbs "ارضعيه - القيه - لا تخافى - لا تحزنى 19 
[suckle - cast him - do not fear - do not grieve] along with

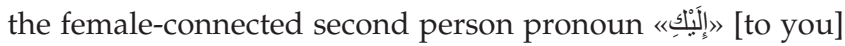
has also given considerable weight to the female gender in this verse.

In all of the above examples, we observed that women are addressed by God. Addressing people directly conveys their importance to the speaker. Needless to say, this issue is rooted in the Arabic language. In this language, and also in many other languages, the present addressee (second person) has a much greater value than the absent (third person). Therefore, direct addressing of women can show the Qur'ān's attention to feminine discourse. Nevertheless, attention to exemplar women shows the height of God's commitment to women in the Qur'ān, a topic that will be dealt with below.

\section{Role models and exemplar women in the Qur'ān}

The second category in the Qur'ānic approach towards women is devoted to verses related to the theme of exemplar women. There is no doubt that the verses including these women create a great distance between Qur'ānic discourse and masculine approaches. In this regard, Maryam and the Pharaoh's wife, Asia, have been mentioned as the role models. Once again, in an independent form, Maryam is considered as a role model. Apart from these applications, the Queen of Saba is also cited as an uncontested and powerful ruler in a celebrated style. ${ }^{13}$ In the Qur'ān 66:11, God first mentions Pharaoh's wife and then introduces her as a role model for all believers, both men and women. Asia's direct dialogue with God in this verse is noteworthy:

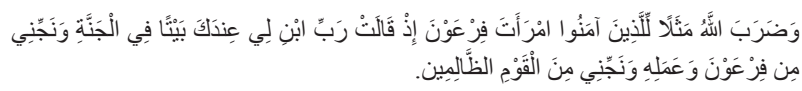

Translation: And Allah presents an example of those who believed: the wife of Pharaoh, when she said, ' $[\mathrm{m}] \mathrm{y}$ Lord, build for me near You a house in Paradise and save me from Pharaoh and his deeds and save me from the wrongdoing people.

In Qur'ān 66:12, Maryam is introduced as a criterion for chastity and honesty. What raises the gender perspective around Maryam is when the story of her service in the temple and her adoption by Zechariah is told. In this narrative, we witness the formation of certain of comparison between Zechariah and Maryam, especially when Zechariah enters the altar and feels surprised to see the food God has sent to Maryam. At this time, he takes Maryam for a model and asks God to give him a child. The confrontation between male and female genders and the relative prominence of Maryam over Zechariah in this Qur'ānic narration are, indeed, remarkable and thoughtprovoking. There is, however, another verse, Qur'ān 27:23, in the Qur'ān that does not have the ideological approach like the previous verses. It mentions the kingdom of Saba and her authority within it. Surah Al-Naml speaks of Solomon's confrontation with a great ruler who is accidentally a woman. When describing her, it is stated that the ruler of the tribe is the woman who possesses all the means and powers of an authoritative ruler. This encounter happens within a complementary context and without the slightest sign of any negative attitudes towards the ruling of a woman. Such verses might be considered as evidence demonstrating the Qur'ān's confirmation of the issue of women leadership, and thus, provides us with evidence of its supportive approach towards the feminine discourse. More evidence is needed to verify the veracity of this claim.

\section{Conclusion}

One of the main merits of this study, which is different from previous related studies, is that it describes and evaluates gender discourses using gender-related linguistic indicators in the Qur'ān. More specifically, all the propositions that are somehow related to the three main gender discourses were extracted and classified into detailed subcategories, and the quality of these discourses and, more generally, the proportion of the use of each discourse type were described. Moreover, this study applied a rather novel method of investigation, that is, it used gender-related language indicators to determine the dominant discourse in the Qur'ān. The results indicated that the language of the Qur'an towards human beings is significantly male oriented; yet, the existence of femalecentred structures, as well as structures that present both female and male, makes Qur'ān's gender approach to human beings varied. Therefore, all three masculine, feminine and egalitarian discourses are present in its text, and they follow a non-linear, complex model.

Accordingly, this detailed description showed that genderrelated linguistic approaches of the Qur'ān are non-linear and complex. Non-linearity of these approaches refers to the variety of the application of gender-related propositions in different place, and their complexity is also because of this very non-linearity, which makes it difficult to understand the direct indications of the propositions. In other words, it is non-linear because the use of gender indicators belonging to a specific gender discourse does not necessarily limit its indication to that particular discourse. For example, the use of a proposition with linguistic indicators belonging to the masculine gender cannot restrict the meaning of that proposition to the same gender, but it can be generalised to both men and women by domination principle or by 'gender consideration'.

\section{Limitations and suggestions for further research}

The research followed a qualitative design, and future researchers can apply quantitative designs to depict a better gender landscape in the Qur'ān. Further quantitative 
analysis of the gender differences in the language of the Qur'an can lead to the discovery of gender-associated layers and different discursive levels. We believe probing Qur'ān's gender discourses and the linguistic devices employed therein to construct those discourses and comparing with those that have been utilised in other religious and literary texts can reveal Qur'ān's distinct and progressive language style.

\section{Acknowledgements}

The authors thank three Qur'ānic scholars, who did not wish to be named for their expert opinions on the interpretations of several verses that the authors found rather difficult to agree on.

\section{Competing interests}

The authors would like to thank Dr Zahra Besharati for helping to prepare the initial notes for this study.

\section{Authors' contributions}

G.D. conceived the idea discussed in this article and proposed it to A.A. and M.N. G.D. and M.N. then suggested and wrote the framework based on which data analysis was conducted. Then, G.D. and M.N. A.A. reviewed and analysed the verses in the Qur'an and wrote the article in Persian. A.A. and M.N. then translated the article into English, and M.N. and G.D. critically reviewed the translated draft multiple times in order to prepare a factually accurate and reader-friendly draft. M.N. proofread the entire article. G.D. formatted the article based on the journal style guide; G.D. also did all the corresponding with the journal.

\section{Ethical consideration}

This article followed all ethical standards for a research without direct contact with human or animal subjects.

\section{Funding information}

This research received no specific grant from any funding agency in the public, commercial or not-for-profit sectors.

\section{Data availability statement}

The data were all extracted from the Qur'ān, which is a publicly accessible book.

\section{Disclaimer}

The views and opinions expressed in this article are those of the authors and do not necessarily reflect the official policy or position of any affiliated agency of the authors.

\section{References}

Abdel Haleem, M.A.S., 1992, 'Grammatical shift for rhetorical purposes: Iltifāt and related features in the Qur'ān', Bulletin of the School of Oriental and African Studies 55(3), 407-432. https://doi.org/10.1017/S0041977X00003621

AbūZayd, N.H., 2000, Dvāer al-Khof (Gheraáton fi Khetab al-Mara', al-Markaz althaghāii al-Arabī, Beirut.

al-Zarkashī, B., 1984, Al-Burhān fi Ulūm al-Qur'ān, Dar al-Ma'refah, Beirut.

Ary, D. (ed.)., 2014, Introduction to research in education, 9th edn., Wadsworth Cengage Learning, Belmont Calif, CA.

Awde, N., 2000, Women in Islam: An anthology from the Qur'än and Hadith', Curzon, Richmond.

Badran, M., 2002, 'Gender', in J. McAuliffe (ed.), EQ, vol. 2, pp. 288-292, E.J. Brill, Leiden.

Barlas, A., 2001, 'Muslim women and sexual oppression: Reading liberation from the Qur'ān', Maclester International 10(1), 117-146.

Barlas, A., 2006, 'Women's readings of the Qur'ān', in J. McAuliffe (ed.), The Cambridge companion to the Qur'ān, pp. 255-273, Cambridge University Press, Cambridge.

Cohen, L., Manion, L. \& Morrison, K., 2007, Research methods in education, Routledge, New York, NY.

Dib, N., 2009, D'un islam textuel vers un islam contextuel: La traduction du Coran et la construction de L'image de la femme, Presses de l'Université d'Ottawa, Ottawa.

Fārūqi, L.L.I., 1984, 'Women in a Qur'ānic society', Al-Tawhid 1, 36-49.

Hidayatullah, A.A., 2014, Feminist edges of the Qur'ān, Oxford University Press, Oxford.

Hsieh, H. \& Shannon, S., 2005, 'Three approaches to qualitative content analysis', Qualitative Health Research 15(9), 1277-1288. https://doi.org/10.1177/ 1049732305276687

Ibn al-Athīr, Z., 1933, al-Mathal al-Sā'ir fi adab al-Kātib wa'l shā'ir II, M. M. ‘Abd alHamid (ed.), Cairo.

Ismail, M.N., 1999, Die Frau im Koran: Verse des Kurans, Die über Offenbarung Allahs, über die Frau, ihr Kindheit, Ehe und Mutterschaft berichtete, Europ. Verlag, Vienna.

Jaśs̄āś, A., 1984, Ahkām al- Qur'ān M.S. Ghamhavi (ed.), Dār Ehyā' al-Turāth al-Arabi, Beirut.

Jeenah, N., 2004, 'Bilqis: A Qur' anic model for leadership and for Islamic feminists', Journal for Semitics / Tydskrif vir Semitistick 13(i-ii), 36-70.

Krippendorff, K., 1989, 'Content analysis', in E. Barnouw, G. Gerbner, W. Schramm, T.L. Worth \& L. Gross (eds.), International Encyclopedia of Communication, vol. 1 pp. 403-407, Oxford University Press, New York, NY.

Lamchichi, A., 1995, 'Statut des femmes dans le discours coranique et la thématique islamiste', in A. Dore-Audibert \& S. Bessie (eds.), Femmes de Méditerranée: Religion, travail, politique, pp. 97-111, Karthala, Paris.

Mills, A.J., Durepos, G. \& Wiebe, E., 2010, Encyclopedia of case study research, vol. 1, Sage, Thousand Oaks, CA

Milot, J., 2009, Egalité hommes et femmes dans le Coran: L'interprétation audacieuse de Mohmoud Mohamad Taha, Médiapaul, Montréal.

Mohaghigh Ḣelli, N., 1987, Sharāye' al-Es/ām fi Masāel al- Halāl va al-Ḣarām, version 2, Eslaeilian Institute, Qum.

Paltridge, B., 2012, Discourse analysis: An introduction, 2nd edn., Bloomsbury, London.

Rahmatulla, S., 2017, Qur'ān of the Oppressed: Liberation theology and gender justice in Islam, Oxford University Press, Oxford.

Rippin, A., 1994, 'The poetics of Qur'ānic punning', Bulletin of the School of Oriental and African Studies 57(1), 193-207. https://doi.org/10.1017/S0041977 X00028238

Ṡadr, S.M., 2001, 'Philosophy of masculinity of Quranic discourse', Quranic Research Quarterly 25 \& 26, 112-131.

Schreier, M., 2014, 'Qualitative content analysis', in U. Flick (ed.), The Sage handbook of qualitative data analysis, pp. 170-183, Sage, Thousand Oaks, CA.

Smith, J.I. \& Haddad, Y.Y., 1982, 'Eve: Islamic image of woman', Women's Studies International Forum 5(2), 135-144. https://doi.org/10.1016/02775395(82)90022-X

Suyūtī, J., 2000, al-Itqān fi Ulūm al-Qur'ān, Dar al-Kitab al-Arabi, Beirut.

Tannen, D., 1994, Gender and discourse, Oxford University Press, Oxford.

Wadud-Muhsin, A., 1995-1996, 'Towards a Qur'ānic hermeneutics of social justice: Race, class and gender', Journal of Law and Religion 12(1), 37-50. https://doi. org/10.2307/1051608

West, C., Lazar, M.M. \& Kramarae, C., 1997, 'Gender in discourse', in T.A. Van Dijk (ed.), Discourse as social interaction, pp. 119-143, Sage, London.

Zahili, V.M., 1988, Al-Fighti al-Es/āmi va Adellatahü, version 4, Dar al-fikr, Damascus. 